\title{
State of the Art of Electric Taxiing Systems
}

\author{
M. Lukic ${ }^{1}$, A. Hebala ${ }^{1}$, P. Giangrande ${ }^{1}$, C. Klumpner ${ }^{1}$, S. Nuzzo ${ }^{1}$, G. Chen ${ }^{1,2}$, C. Gerada ${ }^{1}$, C. Eastwick ${ }^{1}$, M. Galea ${ }^{1,2}$ \\ ${ }^{1}$ University of Nottingham, Nottingham, United Kingdom \\ ${ }^{2}$ Univeristy of Nottingham, Ningbo, China \\ Milos.Lukic@,nottingham.ac.uk; Ahmed.Hebala@nottingham.ac.uk
}

\begin{abstract}
The aviation industry represents an ever-expanding economy and the aircraft market forecast reveals an optimistic growth for the coming decades. New requirements and guidelines call for a more efficient, reliable, and environment friendly aircraft operations during both airborne and ground phases. Considering on-ground operations, the electric taxiing is one of the suggested solutions for reducing the emissions and the acoustic noise in the airport, and for lowering the fuel consumption and the flight costs. This paper provides an overview of the most important existing electric taxiing systems and also presents the basic concepts related to it. Finally, detailed comparison of the different systems is given with recommendations for the future research.
\end{abstract}

Keywords-More Electric Aircraft, Green Taxiing, Electric taxiing, Permanent Magnet Synchronous Machines

\section{INTRODUCTION}

The aerospace industry is currently one of the fastest growing economies in the world and the need for air travel will notably increase in the coming years. This trend is due to the numerous factors such as growth of the regional/national gross domestic product, liberalization policies and tourism [1]. Approximately 3.7 billion passengers were carried by air in 2016, and considering that passenger traffic doubles every 15 years, it is apparent that current fleets will not be able to handle this demand. According to the Airbus Global Market Forecast [2], 34,170 new aircraft are estimated to be manufactured by 2036. In addition to the aircraft that will stay in service, a total of 42,530 passenger aircraft have been estimated to be flying in 2036. Consequently, the fuel consumption and $\mathrm{CO}_{2}$ emissions of the aerospace industry will dramatically rise [3]. The European Commission (EC) has recognized the challenges that this growth will cause and thus the "Flight Path 2050" strategy was signed in 2017 [4]. Besides the challenges in safety and security area, infrastructures, operations etc. this document also aims to mitigate the impact of the air traffic on the environment by agreeing on targets, such as 1) $70 \%$ reduction of $\left.\mathrm{CO}_{2} 2\right) 90 \%$ reduction of $\mathrm{NO}_{\mathrm{x}}$ (compared to 2000 levels) and 3) minimization of noise.

In accordance with these targets, aircraft manufacturers are developing ever more fuel efficient and environmentally friendly aircraft to alleviate pollution concerns and to comply with the goals of the 2050 strategy. The conventional aircraft depends on four main power systems: hydraulics, pneumatics, mechanical and electrical power [5]. Hydraulics is used for the majority of actuation functions. Pneumatics is associated with the system of pressurization, de-icing and air conditioning, whereas electrical power is used for avionics and utility functions. The recent push towards the more electric aircraft (MEA) concept is leading to replace these traditional systems

This work is funded by the INNOVATIVE doctoral programme. The INNOVATIVE programme is partially funded by the Marie Curie Initial Training Networks (ITN) action (project number 665468) and partially by the Institute for Aerospace Technology (IAT) at the University of Nottingham with electrical ones [3]. It is anticipated that MEA and, in the future, all-electric aircraft (AEA) technologies can decrease the weight of aircraft by $10 \%$ and fuel consumption by $9 \%$ [6]. The Boeing 787 Dreamliner is probably the best example of MEA initiative. Indeed, its electrical loads require almost $1000 \mathrm{kVA}$ compared to the $300 \mathrm{kVA}$ of a more conventional Airbus A320 [7]. Taking into consideration different number of maximum passengers on-board, a $72 \%$ increase in terms of power per passenger is registered $(2.78 \mathrm{kVA}$ per passenger for B787 and $1.61 \mathrm{kVA}$ per passenger for A320).

Historically, any effort related to efficiency improvement has mainly focused on the airborne phase, but due to the increasing restrictions, nowadays the ground phase of the flight mission (i.e. taxiing) is also being addressed. According to the International Civil Aerospace Organisation (ICAO), taxiing is the phase of flight in which movement of an aircraft under its own power occurs on the surface of an aerodrome, excluding take-off and landing [8]. Taxiing can be divided into taxi-out and taxi-in. Taxi-out is part of the taxiing from the parking position until the moment of take-off. Taxi-out phase is preceded by the aircraft push-back. Since main jet engines cannot provide reverse thrust, additional tractors and tugs are required to move the aircraft backwards. When aircraft reaches the border to the manoeuvring it is handed to the ground controller which guides it to its assigned runway. During taxiing, the aircraft engines are set to idle mode. Similarly, taxi-in is defined as the phase which begins upon exiting the landing runway and terminates upon arrival at the gate, ramp, apron, or parking area, when the aircraft ceases to move under its own power [8]. Since engines are optimised for cruising speed, they are highly inefficient when used in idle mode and therefore taxiing is addressed as one of the biggest contributors to the pollution and noise at the airports. More than $56 \%$ of the total $\mathrm{NO}_{\mathrm{x}}$ generation in 2002 at Heathrow airport was from taxiing phase [9]. Also, since tractors and tugs are required to push-back the aircraft, the taxiing procedure is slowed down and most importantly this feature reduces the autonomy of any single aircraft. Another factor to consider is that taxi-out time can be quite high, especially at busy airports like Schiphol (AMS) and Heathrow (LHR), which can reach up to $1 \mathrm{~h}$.

In addition to the already mentioned 2050 requirements, also all taxiing procedures are required to be carbon neutral by 2050 . Several solutions have been proposed as alternative to the conventional taxiing and some of them were investigated in [10]. They can be categorized into operational and technological solutions [11]. While operational solutions (such as single engine taxiing) still require engines for the ground movement, the so-called technological solutions focus on engineless taxiing. In turn, these can be grouped into 1) on-board and 2) external advanced ground propulsion solutions (AGPS). In this paper, the terms engineless and electric taxiing will be used 
interchangeably since both on-board and external systems use electric energy at one point of the energy conversion stage, as it will be seen.

Initial studies have shown that in general, electric taxiing system implementation can lead to potential fuel savings, emissions, cost etc. In [9], fuel savings with on-board solutions have been investigated. It is highlighted that the potential fuel savings depend on the type of the aircraft, total taxiing time and flight distance. For instance, short-haul aircraft (e.g. A320) with total taxiing time of 30 minutes and flight distance of 1000 nautical miles (nm) can save 3\% in blockfuel. Based on all US domestic flight missions in 2007 performed by A320 and B737, the total potential saving is estimated to be between $1.1 \%$ and $3.9 \%$ depending on the weight of the system. In [12], studies on the speed limitation of electric taxiing and the ensuing delays were carried out. It was shown that an average speed of $10 \mathrm{~m} / \mathrm{s}$ (approximately 20knots) should not cause significant delays. In [13], an estimated cost saving of $250 €$ per cycle was determined in the worst case scenario of lowest possible savings and highest cost. Considering that one plane makes around 1000 cycles per year air operators can save up to $250 \mathrm{k} €$ annually per aircraft. In [10] fuel savings and emission reductions have been investigated for the various electric taxiing systems. It was found that maximum $\mathrm{CO}$ reductions are obtained with on-board systems, while external systems come with maximum fuel savings but also with the increased $\mathrm{NO}_{\mathrm{x}}$ emissions compared to the conventional taxiing.

Whether using on-board or external system, there are challenges and limitations associated with engineless taxiing. One of the major limitation of the electric taxiing is that jet engines before take-off must be warmed up. In the conventional taxiing that condition is automatically achieved, but in electric taxiing, the main engines are off and they have to be turned on a few minutes before take-off. Hence, a designated area should be provided where aircrafts would be able to turn on engines safely and warm up their engines (maybe something similar to a deicing platform). In addition, due to this limitation electric taxiing would not be beneficial in terms of taxiing time at the airports where this is less than 5 minutes (i.e. a typical taxiing time for engine warm up of A320 or B737). Before these systems come into service, ground control should revise and update rules and policies to be in accordance with the operation of electric taxiing systems. For example, in [14], a study on how the new taxiing system would affect the procedures was presented. Finally, the biggest obstacle is certification. As any new system to be used in aviation, it must go through rigorous series of tests before it is approved by regulatory bodies.

In this paper, a state of the art in electric taxiing systems is presented. Since the first proof of concept presented in 2005, numerous companies have announced the development of various electric taxiing systems. However, many of the projects were discontinued later on or they haven't updated the public in years about their progress. Therefore, the criteria for the selection of the systems under this review were the following: 1) demonstration of successful operation of the system and 2) systems with publicly available up-to-date data either in terms of publications or companies' descriptions and announcements through media. After filtering, five systems had been chosen and they are described in section II. In section III systems are thoroughly compared and advantages and disadvantages of each have been clearly outlined. Furthermore, in the same section, recommendations for the future research are given. Finally, section IV concludes the paper.

\section{REVIEW OF ELECTRIC TAXIING SYSTEMS}

As mentioned in Section I, electric taxiing can be divided into two broad categories: on-board and external systems. The on-board systems are entirely located in the aircraft and are usually based around the concept of the electrical drive comprising an electric motor, power converter and an electric energy source. The external systems use an external car-like vehicle to perform towing of the aircraft, such as shown in Fig. 1 (a). This section discusses the developments of both systems.

\section{A. External Systems}

An example of external ground propulsion system is TaxiBot, a system developed by Israeli Aerospace Industries. TaxiBot is a semi-autonomous hybrid electric tractor, shown in Fig. 1.b, designed to tow the aircraft during all taxiing procedure (push-back, taxi-out and taxi-in). The powertrain of this tractor consists of two diesel engines each driving a separate electric generator which supplies 8 electric motors installed in 4 wheels. Maximum power to the road is $500 \mathrm{~kW}$ with maximum achievable torque of $45 \mathrm{kNm}$ [15]. With these numbers, the tractor can reach a speed of 23 knots towing a full Boeing 737 . It is important to emphasize that the tractor is steered by the pilot through the tiller as in normal taxiing, which is important feature because of safety, accountability and regulatory reasons [16]. This is possible using a unique towbarless nose landing gear (NLG) interface clamping mechanism mounted on a rotating turret platform. Sensors which are installed at the platform detect the steering angle of the NLG and steer all wheels of the tow tractor [17]. Furthermore, braking is also achieved as in conventional taxiing, using brake pedals that control brake system in the main landing gear (MLG) [16]. Although pilot controls most of the taxiing process, the driver is still required for pushback operations, for returning the vehicle after the

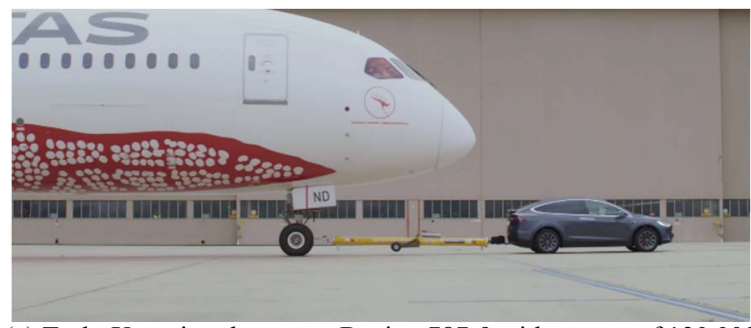

(a) Tesla-X towing the empty Boeing 787-9 with a mass of 130,000

$\mathrm{kg}$.

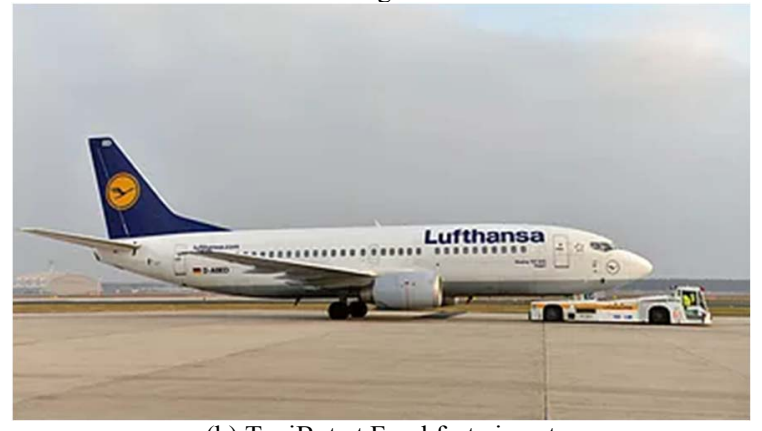

(b) TaxiBot at Frankfurt airport

Fig. 1 Examples of external electric taxiing systems 
aircraft's take-off and in case of emergency. The company offers two models: 1) narrow body model and 2) wide body model.

Certification for use with the Boeing 737 has been issued by the European Aerospace Agency (EASA) in November 2014, and since then three narrow body models have been operating for Lufthansa LEOS (ground handling company of Lufthansa) at Frankfurt International airport. In May 2017, TaxiBot was certified by EASA for the A320 family (both ceo and neo), followed by the Federal Aviation Administration (FAA) certification for Boeing 737 family in October 2017. EASA's certification is also valid for the FAA. Thus, TaxiBot is the only certified and commercially-operational alternative taxing solution up to date [18].

\section{B. On-Board Systems}

As discussed earlier, a typical on-board system would include an electrical drive concept with an electric motor, power converter and an electric energy source. Several questions arise for each element of this system and all of them will be discussed and described when presenting the available systems. The two most important questions are a) the location of the driving motor and $b$ ) the source of the electrical energy. Regarding the location of the motor, the options are either integration at the NLG or at the main landing gear MLG. The energy required could be supplied through the auxiliary power unit (APU) or "more-electrically" through batteries and fuel cells. For each of the following systems, this section shows which options have been adopted.

In the process of developing into MEA and AEA, the aircraft on-board electrical systems would require a set of enhancements. These are set to meet the mandatory high requirements of aerospace industry. Considering these requirements, the drive system design has to address the following factors: reliability, power density, torque density, efficiency, controllability, fault tolerant capability, thermal robustness, complexity of design and fabrication [6], [19], [20].

WheelTug was the first company to demonstrate the operation of an on-board electric taxiing system, as shown in Fig. 2, back in 2005. The system depends on two induction machines from Chorus Motors, located at the NLG [21]. The APU powers the motors during the taxiing. This solution still uses fossil fuel product and hence it is not completely emission and noise free, although levels are much lower than during normal taxiing operation [10]. Designers of this system highlight several benefits of using WheelTug in addition to the general benefits of electric taxiing that have already been mentioned. Firstly, this system has the advantage of reducing the push back time to 8 minutes per flight, which is a significant time reduction especially for short and medium haul flights. Also, WheelTug emphasizes the possibility of parking parallel to the terminal building, since jet engines are turned off. Consequently, two airport bridges can be used for boarding increasing the passenger comfort and more importantly it would reduce the turnaround time (TAT) and consequently the cost of the flight [22].

The proof of concept was demonstrated in 2005 on a Boeing 767. The second ground test was performed in 2010 to further prove that the system would still be reliable in snowy and slushy conditions [23]. Finally, in 2012, a full in-wheel motor

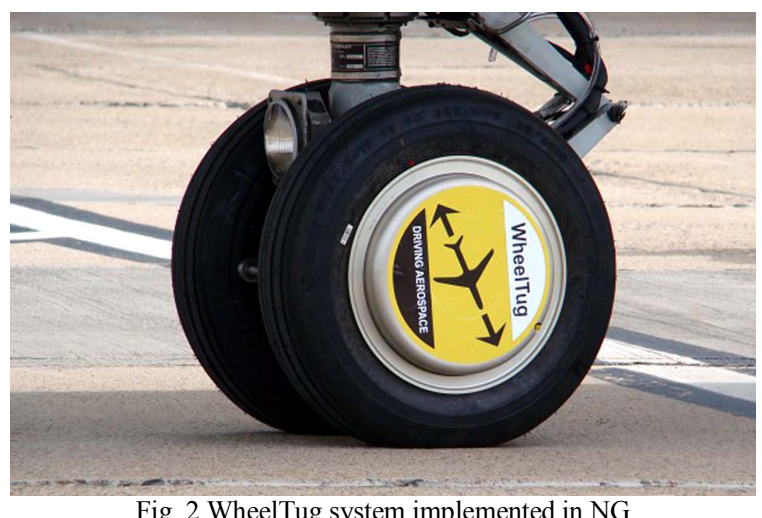

operation was demonstrated at Prague airport using Germania's Boeing 737 [24], [25].

As of now, the company has 1072 orders over 20 airline companies [26], even though they are still in the process of certification. The latest news regarding certification (January 2017 [27]) is that WheelTug is officially in the process of certification for Boeing 737 by the FAA and that Air Transat volunteered to offer the plane to support certification efforts. Also, Stirling Dynamics, a UK leader in landing gear development, has been chosen by WheelTug to develop NG systems that will be used in its certification efforts [28]. The system is envisaged to enter in service in late 2018/ early 2019.

Following the successful demonstration activities of WheelTug, developments of electric taxiing continued with other companies. Collaborations between the German Aerospace Centre (DLR) and Lufthansa Technik is one of them. The DLR motor is located also at the NLG and consists of a permanent magnet synchronous motor (PMSM). The two motors and gears installed in the wheel rim are shown in Fig. 3. The motors can produce $2.25 \mathrm{kNm}$, driving the 80 ton of the A320 at a top speed of $25 \mathrm{kmph}$. The proposed PMSM uses Neodymium iron boron magnets, which indeed have high remnant flux density. On the other hand, they have a relatively high costs and are quite unstable with the temperature and not widely available. The system was developed to be powered from the fuel cells [29], [30]. Despite the major advantages of using these technology, such as low on-ground noise and low fuel consumption, fuel cells are still technologically immature. The system was tested in 2011 at Hamburg Finkerwerder airport using an Airbus A320 [31]. The total power of 50kW [32] and other limitations, such as hydrogen storage and safety, make this system the least possible to be seen operating in the near future.

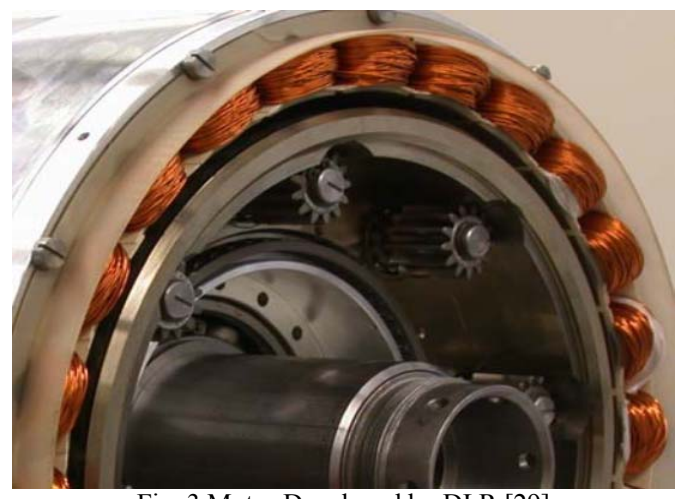

Fig. 3 Motor Developed by DLR [29] 
All the systems discussed above are installed at the NG. Regarding the MLG configuration, Safran has advanced the furthest in collaboration with other companies and universities. Safran and Honeywell Aerospace created a joint venture in 2011 called the Electric Green Taxiing System (EGTS). The system was designed in accordance to the EGTS requirements [33], namely 1) 20 knots speed in $90 \mathrm{sec}$, 2) 10 knots speed in $20 \mathrm{sec}$ for active runway crossing and 3) breakaway torque at $1.5 \%$ slope at maximum take-off weight (MTOW). The system was successfully tested at the Paris International Air Show (PAS) in 2013 using an A320, as shown in Fig. 4. Fig. 5 presents an illustration of the basic scheme of the electric drive system (EDS) which comprises an ac-to-dc converter, an autotransformer rectifier unit (ATRU), a wheel actuation control unit (WACU) and a traction motor (TM). As can be observed, the system was powered through the APU. No information about the electrical motor implementation is available, however it can be perceived that gears were used [34]. The maximum demonstrated speed was 10 knots due to PAS safety regulations, but later at Toulouse airport speeds of 20 knots were achieved. Even though the demonstration was successful, Safran and Honeywell decided to terminate the project in 2016. However, Safran decided to stay devoted to the electric taxiing idea, through its involvement in the Clean Sky 2 framework [35]. An important project in this framework, led by Safran Landing Systems, is known as "high energy storage module for an electric taxi" through which optimum energy storage system should be designed up to TRL6 [35].

Safran also collaborated with University of Nottingham, Airbus, Adeneo and DLR under the CleanSky Joint Technology Initiative. The study conducted in [36], [37] is continuing the work of [30], with the aim of developing a direct drive system that removes the need for any mechanical advantages such as gearing. An investigation to identify the optimal position in the MLG of an A320 concluded that employing the electric taxiing motor at the back envelope of the

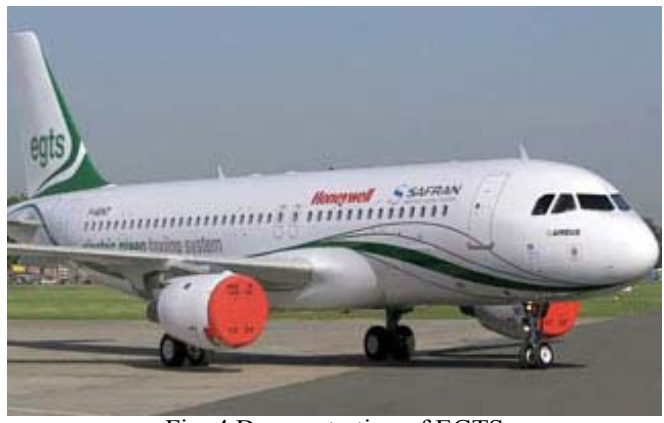

Fig. 4 Demonstration of EGTS

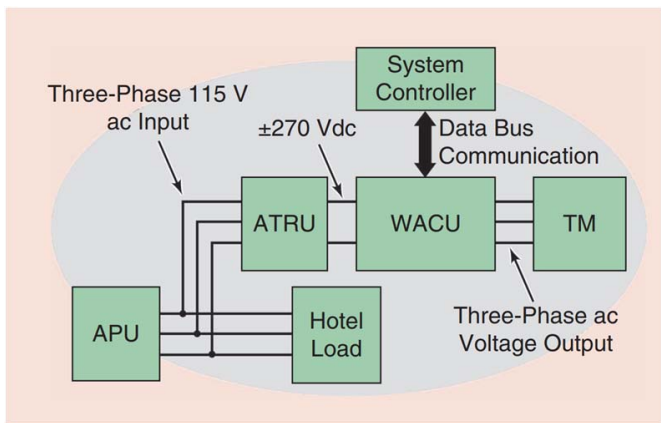

Fig. 5 Architecture of EDS of EGTS 「341

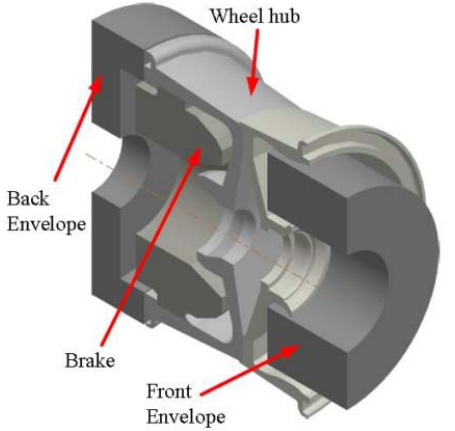

Fig. 6 Typical arrangement of wheel at the MLG [30]

MLG is the optimum solution because of the more available space as shown in Fig. 6. A main challenge with implementing the drive into the MLG is of course the lack of space. A PMSM was developed for the system and through several torque enhancement techniques [38] managed to reach a recordholding $42 \mathrm{Nm} / \mathrm{kg}$ in terms of peak torque density. The operating torque reached from this machine is $7000 \mathrm{Nm}$ and it comprises various features such as 1) an outer rotor configuration, 2) a five stage Halbach array configuration, 3) a double star winding configuration and 4) various advanced materials such as Cobalt Iron and Samarium Cobalt magnets [39],[40], [41]. This machine was then implemented with a power electronics converter developed by Adeneo, a control algorithm developed by DLR and tested up to TRL5 standards in a realistic environment in the labs of Safran Landing Systems in France.

\section{COMPARISON OF THE ET SYSTEMS AND RECOMMENDATIONS TOWARDS FULLY-INTEGRATED ZERO CARBON TAXIING}

\section{A. Comparison of the ET systems}

The most important advantage of external systems is that they do not add to the on-board weight. Also, since modifications done to the aircraft are minor, the certification process is considerably easier for external systems. However, the main disadvantage of this system is that congestion at surface level would increase and modifications to the airport infrastructure would need to be made, such as additional roads for tractor movement after aircraft's take-off. Also, usage of these systems during taxi-in can be seamless, considering that taxi-in is usually shorter than taxi-out due to the non-zero initial speed. After the landing the aircraft would have to stop and wait a few minutes to be attached to the tractor, while perhaps without stopping could even be at the terminal building.

On the other hand, on-board systems have the advantage of minimizing the airport surface movements of towing tractors, compared to external systems. Basically, an aircraft could become completely autonomous. Also push-back time is notably lower since aircraft are able to do pushback autonomously. However, the main drawback of the on-board systems is the increase of the total aircraft weight. Therefore, benefits of the saved fuel on ground could be theoretically offset by higher fuel consumption during airborne phase. Another major challenge of on-board systems is the change of the aircraft architecture, which would require considerable efforts in terms of certification and legislations.

As seen in the previous sections, there are different on-board solutions. The NLG configuration benefits from the larger 
available space which is not the case in MLG due to the presence of the brakes. Despite the challenging confined space available at the MLG, it carries around $90 \%$ of the aircraft weight, making it highly appealing for motor installation due to the possible high tractive forces. Hence, at severe conditions such as snow, ice and rain when traction efforts are reduced, the installation of the ET at the NLG would be problematic. Furthermore, MLG consists of four wheels, which makes it possible for implementation of four motor system. This would increase the reliability and redundancy and at the same time it would allow higher flexibility in the designing of the motor. Also one of the biggest advantages is the improved life times of the carbon brakes. For example, during taxing with EGTS, the carbon brakes are not used extensively as when taxiing with the main engines on. However, the biggest challenges remain the heat management generated from the brakes and the installation of appropriate cooling systems for the motors.

A major difference between any on-board ET systems is the method of motor and wheel integration. It can either be direct drive or a geared system. In case of using direct drive, the system would benefit of simpler drive train construction, higher overall efficiency, possibly reduced weight and increased reliability. On the other hand, the motor should be able to handle the huge amount of peak torques required and the high speed operation during landing and take-off. In case of PMSMs, a high back-emf could lead to winding failures, PM demagnetization, and converters damages. The presence of gears simplifies the installation of clutch systems which could solve the problem of back-emf. However, jamming and complex mechanical drive train are still the main disadvantages of using geared system.

\section{B. Recommendations for further research}

Multiphase machines represent a potential solution for increasing the power density, reducing torque ripple and improving the reliability [42]. The use of superconducting motors should be considered as an alternative for the ET motors because they have a relatively high torque density. Authors in [43], [44] present a study of using it for propulsion application. Because of the confined space and the need for simplicity, it is more convenient to use active air cooling rather than liquid cooling. Furthermore, novel machine types can be further investigated for this application, such as IM with conical rotor [45].

Research and developments of energy storage devices and associated power electronics is essential for on-board ET systems. Installation of local energy storage system (ESS) would allow energy to be captured during braking events and would improve overall performance of the drive. Additionally, the installation of local energy storage would decrease the dependence from the APU. Finally, by using energy storage there is possibility of complete emission-free taxiing. Considering power and energy requirements of the system together with the specific energy and power of currently available storage technologies, Li-ion batteries and supercapacitors arise as top candidates. Introduction of the ESS would increase the overall weight of ET system. Therefore, energy storage should be as compact and light as possible. For instance, target mass of Clean Sky 2 project [35] for the whole unit is $40 \mathrm{~kg}$. The storage elements might be charged while the aircraft is parked (plug-in charge), charged during regenerative braking or even charged during regeneration of other electrical systems on the aircraft. All of these possibilities are just one direction in which future work regarding storage can move.

\section{CONCLUSIONS}

This paper presented a review of the ET systems, technologies, challenges and future trends. Global challenges of aviation have been overviewed with the emphasis on the environmental issues. In line with the requirement that all taxiing procedures should be carbon free by 2050, many research effort has been investigated into aircraft taxiing operations. In this paper, ET systems that have been successfully demonstrated have been reviewed. All presented systems assume engineless operation, i.e. jet engines are turned-off during taxiing. However, none of them is fully electric and zero carbon, besides DLR which uses fuel cell with water as waste. Feasibility studies regarding economy and operations that have been presented showed that implementation of existing ET systems can potentially reduce $\mathrm{CO}_{2}, \mathrm{NO}_{\mathrm{x}}$ and noise.

As already alluded, on-board solutions are the most suitable for narrow-body aircraft, which have many flight cycles during the day with high taxiing time. For wide-body aircraft, the fuel savings during taxiing would be cancelled during the flight phase due to having extra on-board weight. Therefore, one possible scenario to be foreseen is a mixture of the two types: on-board for narrow-bodies and external systems for widebodies aircraft. However, the final decision will have to be made by the airline companies in accordance to their network and aircraft utilization. For instance, KLM's B737 which flies LHR-SCH route might see the benefits of on-board system implementation, while no benefit would be seen for the same aircraft type flying between airports with small taxiing times.

In case of using on-board systems, installation of the ET at the main lading gears seems to be the more reasonable solution, as this is s responsible for carrying the majority of the aircraft weight. The motor configuration is challenging, as each configuration possesses several advantages and disadvantages. PMSMs are usually the first choice for ET traction motor, because of their high torque density and efficiency. Nevertheless, the heat management of PMSMs is a concern, especially when located in the MLG and near the brakes. Air cooling is the more suitable solution for this application because of the confined space available. Elimination of gears and clutches are highly recommended. Future use of multiphase machines for this application would highly increase the reliability and decrease the torque ripples.

Finally, some of the operational challenges of ET systems have been addressed (impact on ground control, regulations and certifications) as well as recommendations for future research effort in the field, such as local energy storage development, novel cooling system solutions and innovative electric machine topologies.

\section{REFERENCES}

[1] European Comission (March 2017), "Annual Analyses of the EU Air Transport Market 2016." [Online]. Available: https://ec.europa.eu/transport/sites/transport/files/2016_eu_air_transport_i 
ndustry_analyses_report.pdf[Accessed: 16 - May - 2018].

[2] Airbus S.A.S., "Global Market Forecast: Growing Horizons 2017/2036." [Online]. Available:

https://ec.europa.eu/transport/sites/transport/files/2016_eu_air_transport_i ndustry analyses report.pdf [Accessed: 16 - May - 2018].

[3] V. Madonna, P. Giangrande, and M. Galea, "Electrical Power Generation in Aircraft: review, challenges and opportunities," in press on IEEE Transactions on Transportation Electrification, DOI: 10.1109/TTE.2018.2834142, 2018.

[4] European Comission, "Flightpath 2050, Europe's Vision for Aviation." [Online]. Available: https:/ec.europa.eu/transport/sites/transport/files/modes/air/doc/flightpath 2050.pdf [Accessed: 16 - May - 2018].

[5] M. Galea, C. Gerada, T. Raminosoa, and P. Wheeler, "Design of a high force density tubular permanent magnet motor," 19th Int. Conf. Electr. Mach. ICEM 2010, pp. 10-15, 2010.

[6] W. Cao, B. C. Mecrow, G. J. Atkinson, J. W. Bennett, and D. J. Atkinson, "Overview of electric motor technologies used for more electric aircraft (MEA)," IEEE Trans. Ind. Electron., vol. 59, no. 9, pp. 3523-3531, 2012.

[7] X. Roboam, B. Sareni, and A. De Andrade, "More Electricity in the Air," Ind. Electron. Mag. IEEE, vol. 6, no. 4, pp. 6-17, 2012.

[8] "ICAO." [Online].

Available: https:/www.icao.int/safety/airnavigation/AIG/Documents/ADREP Taxonomy/ECCAIRS Aviation 1.3.0.12 (VL for AttrID 391 - Event Phases).pdf. [Accessed: 26-Jun-2018].

[9] N. Dzikus, J. Fuchte, A. Lau, and V. Gollnick, "Potential for Fuel Reduction through Electric Taxiing," 11th AIAA Aviat. Technol. Integr. Oper. Conf., no. September, pp. 1-9, 2011.

[10] R. Guo, Y. Zhang, and Q. Wang, "Comparison of emerging ground propulsion systems for electrified aircraft taxi operations," Transp. Res. Part C Emerg. Technol., vol. 44, pp. 98-109, 2014.

[11] L. Khammash, L. Mantecchini, and V. Reis, "Micro-simulation of airport taxiing procedures to improve operation sustainability: Application of semi-robotic towing tractor," 5th IEEE Int. Conf. Model. Technol. Intell. Transp. Syst. MT-ITS 2017 - Proc., pp. 616-621, 2017.

[12] P. C. Roling, P. Sillekens, R. Curran, and W. D. Wilder, "The effects of Electric Taxi Systems on airport surface congestion," 15th AIAA Aviat. Technol. Integr. Oper. Conf., no. June, pp. 1-10, 2015.

[13] J. Hospodka, "Cost-benefit analysis of electric taxi systems for aircraft," J. Air Transp. Manag., vol. 39, pp. 81-88, 2014.

[14] N. Okuniek and D. Beckmann, "Towards higher level of A-SMGCS: Handshake of electric taxi and trajectory-based taxi operations," 2017 IEEE/AIAA 36th Digital Avionics Systems Conference (DASC), St. Petersburg, FL, 2017, pp. 1-10.

[15] "A Tractor that Saves Tons of Aviation Fuel." [Online]. Available: https://www.siemens.com/innovation/en/home/pictures-ofthefuture/mobility-and-motors/electromobility-aircraft-tractors.html. [Accessed: 03-Jul-2018].

[16] "TaxiBot-International." [Online]. Available: http://www.taxibotinternational.com/. [Accessed: 16-May-2018].

[17] "Pilot controlled dispatch towing - without engines running." [Online]. Available: http://www.lufthansa-leos.com/taxibot. [Accessed: 02-Jul2018].

[18] "TaxiBot - Green revolution in airplane taxiing." [Online]. Available: http://docs.wixstatic.com/ugd/865bf2_9eb200929c4a42108ecf23d94e5c1 379.pdf. [Accessed: 27-Jun-2018].

[19] A. Al-Timimy, G. Vakil, M. Degano, P. Giangrande, C. Gerada and M. Galea, "Considerations on the Effects That Core Material Machining Has on an Electrical Machine's Performance," in IEEE Transactions on Energy Conversion, vol. 33, no. 3, pp. 1154-1163, Sept. 2018.

[20] A. Al-Timimy et al., "Design and Losses Analysis of a High Power Density Machine for Flooded Pump Applications," in IEEE Transactions on Industry Applications, vol. 54, no. 4, pp. 3260-3270, July-Aug. 2018.

[21] "Chorus [Online]. Motors." Available: http://www.chorusmotors.com/aerospace.php. [Accessed: 02-Jul-2018]

[22] "WheelTug Webinar: Cheaper, Safer, and More Comfortable - You Can Have All Three!" [Online]. Available: https:/www.youtube.com/watch?v=2eeAMtbJuU8. [Accessed: 02-Jul2018].

[23] "WheelTug® Tow Tests Successful in Prague." [Online]. Available: http:/www.marketwired.com/press-release/wheeltugr-tow-testssuccessful-in-prague-1364008.htm. [Accessed: 26-Jun-2018].
[24] "WheelTug Successfully Tests Electric Drive System on Boeing 737NG." [Online]. Available: http:/www.marketwired.com/pressrelease/wheeltug-successfully-tests-electric-drive-system-on-boeing737ng-1672869.htm.

[25] "WheelTug June 2012 Prague Ground Tests." [Online]. Available: https://www.youtube.com/watch?v=vfueF1iQrz4. [Accessed: 26-Jun2018].

[26] "WheelTug." [Online]. Available: http://www.wheeltug.com/news.php [Accessed: 22 - May - 2018].

[27] "Flight Global." [Online]. Available: http://dashboard.flightglobal.com/app/\#/. [Accessed: 26-Jun-2018].

[28] "STIRLING REDESIGNS THE WHEEL!" [Online]. Available: https://www.stirling-dynamics.com/news/stirling-redesigns-wheel/. [Accessed: 02-Jul-2018].

[29] M. Schier, F. Rinderknecht, A. Brinner, and H. Hellstern, "High Integrated Electric Machine for Aircraft Autonomous Taxiing," Int. Conf. Electr. Veh. Renew. Energies (EVER 11), 2011.

[30] T. Raminosoa, T. Hamiti, M. Galea, and C. Gerada, "Feasibility and electromagnetic design of direct drive wheel actuator for green taxiing," IEEE Energy Convers. Congr. Expo. Energy Convers. Innov. a Clean Energy Futur. ECCE 2011, Proc., pp. 2798-2804, 2011.

[31] "DLR Airbus A320 ATRA taxis using fuel cell-powered nose wheel for the first time." [Online]. Available: https:/www.dlr.de/dlr/en/desktopdefault.aspx/tabid-10204/296 read931/\#/gallery/2078. [Accessed: 02-Jul-2018].

[32] F. Re, "Model-based Optimization, Control and Assessment of Electric Aircraft Taxi Systems," 2017.

[33] "EGTS." [Online]. Available: https://www.arts-etmetiers.asso.fr/manifestation_cr/678_compte_rendu.pdf [Accessed: 16 May - 2018].

[34] E. D. Ganev, "Electric Drives for Electric Green Taxiing Systems: Examining and Evaluating the Electric Drive System," in IEEE Electrification Magazine, vol. 5, no. 4, pp. 10-24, Dec. 2017.

[35] European Comission (March 2017), "Annex VI : 6 th Call for Proposals ( CFP06 ) - List and Full Description of Topics." [Online]. Available: https://ec.europa.eu/research/participants/portal/doc/call/h2020/jti-cs22017-cfp06-air-01-25/1762608-cfp06 description of topics en.pdf. [Accessed: 16-May-2018].

[36] D. Golovanov, M. Galea, and C. Gerada, "High specific torque motor for propulsion system of aircraft," 2016 Int. Conf. Electr. Syst. Aircraft, Railw. Sh. Propuls. Road Veh. Int. Transp. Electrif. Conf. ESARS-ITEC 2016, 2017.

[37] M. Galea, Z. Xu, C. Tighe, T. Hamiti, C. Gerada, and S. Pickering, "Development of an aircraft wheel actuator for green taxiing," Proc. - 2014 Int. Conf. Electr. Mach. ICEM 2014, pp. 2492-2498, 2014.

[38] M. Galea, T. Hamiti, and C. Gerada, "Torque density improvements for high performance machines," Proc. 2013 IEEE Int. Electr. Mach. Drives Conf. IEMDC 2013, pp. 1066-1073, 2013.

[39] C. Sciascera, P. Giangrande, L. Papini, C. Gerada, and M. Galea, "Analytical Thermal Model for Fast Stator Winding Temperature Prediction," IEEE Trans. Ind. Electron., vol. 64, no. 8, 2017.

[40] A. Hebala, O. Hebala, W. A. M. Ghoneim, and H. A. Ashour, "Multiobjective particle swarm optimization of wind turbine directly connected PMSG,” 2017 19th Int. Middle-East Power Syst. Conf. MEPCON 2017 Proc., vol. 2018-Febru, pp. 19-21, 2018.

[41] A. Hebala, W. A. M. Ghoneim, and H. A. Ashour, "Different design approaches of surface mounted high performance PMSG," 2017 Intl Conf Adv. Control Circuits Syst. Syst. 2017 Intl Conf New Paradig. Electron. Inf. Technol., no. 1, pp. 85-90, 2017.

[42] O. Grigore-Müler and M. Barbelian, "Regenerative braking for aircraft landing roll phase using an electric machine," 2012 13th Int. Conf. on Optimization of Electrical and Electronic Equipment, Brasov, 2012.

[43] J. S. Thongam, M. Tarbouchi, A. F. Okou, D. Bouchard, and R. Beguenane, "Trends in naval ship propulsion drive motor technology," 2013 IEEE Electr. Power Energy Conf. EPEC 2013, pp. 1-5, 2013.

[44] D. Dezhin, N. Ivanov, K. Kovalev, I. Kobzeva, and V. Semenihin, "System Approach of Usability of HTS Electrical Machines in Future Electric Aircraft," IEEE Trans. Appl. Supercond., vol. 28, no. 4, 2018.

[45] S. Roggia, F. Cupertino, S. Member, C. Gerada, and M. Galea, "A TwoDegrees-of-Freedom System for Wheel Traction Applications,” vol. 65, no. 6 , pp. 4483-4491, 2018. 